\title{
Mesquite (Prosopis juliflora) plant prevalence in different districts of Balochistan \& antibacterial activity of its pods
}

\author{
Muhammad Essa*, Shakeel Babar and Zia Uddin \\ Biotechnology \& Molecular Biology Department (CASVAB), University of Balochistan, Quetta, Balochistan- \\ Pakistan \\ *Corresponding author's email: dfoessa@gmail.com \\ Citation \\ Muhammad Essa, Shakeel Babar and Zia Uddin. Mesquite (Prosopis juliflora) plant prevalence in different \\ districts of Balochistan \& antibacterial activity of its pods. Pure and Applied Biology. Vol. 6, Issue 4, pp1503- \\ 1515. http://dx.doi.org/10.19045/bspab.2017.600162
}

\begin{tabular}{llll}
\hline \hline Received: 19/10/2017 & Revised: 08/11/2017 & Accepted: 19/11/2017 & Online First: 08/12/2017 \\
\hline \hline
\end{tabular}

\section{Abstract}

This study was conducted to evaluate in vivo multiple uses of mesquite plant, identification of selected areas in Balochistan and anti-bacterial activity of mesquite pods (alkaloid-enriched extracts). For this purpose a survey was conducted in areas where mesquite plant prevails. Pods of mesquite were collected from different trees standing at Yaro Pishin Roadside Plantation and were brought to the physiology laboratory of Centre for Advanced Studies in Vaccinology \& Biotechnology (CASVAB) University of Balochistan Quetta. Pods were dried and extract was obtained which was subjected to check antibacterial activity through two different methods. The inhibition zones of bacteria were measured in $\mathrm{mm}$. It was concluded that mesquite, which was once viewed as weed, its pods have antibacterial components. Furthermore, this study indicated that mesquite is a useful plant if properly managed.

Keywords: Prosopis juliflora; Pods; Balochistan; Antibacterial activity

\section{Introduction}

Mesquite (Prosopis juliflora) is woody legumes found in arid and semiarid areas of Northern and Southern America, Mexico, Northern Africa and Eastern part of Asia. Mesquite have more than 40 species, originated from South America [1]. Although the geographical dispersion of mesquite plant is stable, its density have amplified in the recent past which have been attributed to anthropogenic activities or dissemination of mesquite seed by the livestock [2].

Actually mesquite (genus Prosopis) is a thorny wild shrub occurring in arid and semiarid zones of the world. Mesquite species is multipurpose evergreen and at cold areas deciduous shrub / tree with straight and thorny arm producing fruit called pods. In shallow soil mesquite grows as a small shrub whereas in deep soil it gets height as tall as 50ft making rounded canopy with availability of adequate moisture. Thus mesquite plants have different size and shape, subject to growing conditions and water availability. If seedlings of mesquite plants are not damaged by weather or animals, trees may get 40- 50 feet height, with a large canopy. If the seedling is injured, the plant grows into an extensive multi-trunked shrub.

Mesquite is one of the most economically and ecologically important shrubs or tree, which are found in arid and semi-arid zones 
of North and South America, North Africa and East Asia. More than 40 species of mesquite are originated from South America [1]. Mesquite dispersal has been attributed to anthropogenic activities such as suppression of natural fires or dispersion of mesquite seed by the herding and journey of domestic livestock [2]. Mesquite are also referred to as Algarroba. The genus Prosopis has 44 species which that have been known [3]. The genus Prosopis is highly adapted to arid lands of Northern, Southern America, Central America and the Caribbean [4]. It is adapted to a wide range of differences in temperature i.e. 12 to 50 ${ }^{\circ} \mathrm{C}$. It can also tolerate drought condition i.e. regions where rainfall is less than 500 $\mathrm{mm}$ per year. Mesquite pods are regarded as highly sugar content pods and it is said that pods are included in human diet and cattle fodder for thousands of years. About $100 \mathrm{G} /$ $\mathrm{Kg}$ of dried material, with $40 \mathrm{G} / \mathrm{Kg}$ of rough protein on a dried material base (DM), pods have been used in semi-arid and arid areas of the world for centuries by human and cattle in diet. Mesquite pods contains toxins and polyphenolics, limiting uses of the pods as fodder for animals. Algaroba is noticed in cattle in many parts of the World. Medical symptoms, includes mandibular sensations, lethal saliva, problems in assimilation and twisted head, with many more symptoms such as cranial nerves function interruption, are common in small ruminants. Extended combination of algarroba in cattle foods is much lethal. Cattle are given diets having less than $40 \mathrm{~g}$ of dry algaroba beans/100 g DM, to avoid intoxication particularly when the nourishing duration surpasses two months. Mesquite perhaps originated in Peru or Mexico, now it is found as wild weed in semi-arid and arid zones of North America, South America, Central America, Mexico and Southern parts of United States of America. Mesquite has been brought into tropical regions such as North-eastern Brazil, Africa, Southeast Asia and Southern parts of Asia. Basically mesquite was transported in barren arid zones of the world as a valuable feed, source of energy and shade shrub. However, mesquite with the passage of time evolved into an unwanted invader weed species, especially in regions where water is scarce.

Though the terrestrial dispersal of mesquite in the South Western United States of America persisted constant but mesquite density amplified with the late $19^{\text {th }}$ century. This terrestrial dispersal has been accredited to man's influence through overpowering of natural fires and broadcasting of mesquite seed by the movement of domestic cattle [2].

Though mesquite plants are not highly toxic, yet there are parts of the plant that may have adversative effects. Mesquite seeds may cause digestive problems if eaten [5].Although the spines of mesquite aren't toxic, they may result soreness. The flowers are allergic and the pollen may cause hay fever [5].The resin might also become source of irritation [6].

Mesquite is largely used for feeding cattle's. Prosopis pods comprises cytotoxic alkaloids that may result intoxication in domestic animals if feed having high levels of pods $(>50 \%)$ which have been reported in USA, Peru and Brazil [7-9]. Toxicity is also reported if a wet pod after rainfall was eaten by animals [10]. Dried Prosopis pods are given to goats as the only forage during 4 days suffered from diseases such as partial anorexia, bloody diarrhea, histological lesions in the liver, and rarefaction of lymphoid tissue [11].

Mesquite is an evergreen shrub which has extensive root system and can reach up to $40 \mathrm{~cm}$ in just eight weeks. It also grows fast after germination [12]. This characteristic helps it to invade in new regions. Mesquite is viewed strictly as a weed that needed to be eradicated, due to its intrusive nature as Its intrusive nature is specious from the fact that it can grow with a piece of root left in the soil. Because of this fact, it is often referred to as a "noxious weed". Though mesquite is fast growing species in saline soils of arid zones with good nitrogen fixing value [4, 13].Still mesquite has been 
considered as weed in many parts of the world $[3,14,15]$.

\section{Mesquite origin and dispersion in Pakistan}

Pakistan is located in South Asia. The total area of Pakistan is 7,969,096 sq. km, out of which $88 \%$ is classified as arid and semiarid. The genus Prosopis is highly adapted to arid lands [4]. Balochistan, a province of Pakistan, with an area of 347, 200 sq. km, makes up $44 \%$ of the total geography the country [16]. Balochistan is southwestern province of Pakistan, between 250 to $320 \mathrm{~N}$ latitude and 600 to $720 \mathrm{E}$ longitudes. It is the largest province of Pakistan. It is generally said that more than $90 \%$ of the total land surface of Balochistan is rangeland but unfortunately the biomass productivity of most of the rangelands is very low .Still livestock rearing is a major profession of the people of Balochistan and it is evident from the fact that $87 \%$ of local people of Balochistan get their livelihood directly or indirectly from livestock rearing [17].

In Pakistan mesquite is usually famous as mesquite and its local name is Vilayati Kabul Kikar [18]. Probably mesquite was brought into Sindh at late 19 century, probably from Jamaica or Mexico. Primary purpose of the introduction of mesquite in the sub-continent was for reclamation of sand dunes stabilization and providing a valuable source of income to the poor. Mesquite was propagated in Pakistan during 1950s and 1960s. In early 1970s mesquite dispersed into many regions of Sindh, Punjab and Balochistan province. Mesquite was propagated in district Gawadar, Balochistan for sand dunes movement stabilization. Mesquite is found in semi-arid arid and arid zones of Pakistan [19]. It is one of the dominant intrusive species in Karachi [20]. It is also noted in Punjab and coastal areas of Balochistan [21]. In Northern Areas of Pakistan up to Kashmir, it is commonly found as weed [14]. Mesquite is one of the major exotic intrusive species in Pakistan [18]. In Gwadar, a district of Balochistan, Mesquite is propagated, for the stabilization of sand dunes movement [22]. Now Mesquite pods are a major source of forage for cattle in many parts of Balochistan. Mesquite grows in the arid and semi-arid areas of Balochistan. Districts of Pishin, Harnai Bolan, Loralai, Sibi, Jaffarabad, Jhalmagsi, Barkan, Musa Khail, and Barkan, are main districts where mesquite dispersal was observed.

\section{Taxonomic features}

Prosopis juliflora identification is not difficult due to its leave structures, spines and unique identification features $[15,23]$.

Present name: Prosopis juliflora

$\begin{array}{ll}\text { Family: } & \text { Leguminosae } \\ \text { Sub-family } & \text { Mimosoideae } \\ \text { Genus } & \text { Prosopis } \\ \text { Species. } & \text { Juliflora }\end{array}$

Local name (Paksitan)

Common Name (Urdu): Vilayati babul, Kikar

Common Name (Punjabi): Vilayati

Kikar, Pahari Kikar

Common Name (Sindhi): Devi

Common Name (Pashto): Nargahi

Common Name (Balochi): Walloor

Common Name (English): Algarroba,

honey mesquite, mesquite.

\section{Mode of distribution pattern}

In several parts of Pakistan, Prosopis juliflora occurs and grows in following ecological conditions.

Altitude: -

$0-1500 \mathrm{~m}$

Mean annual temp:

$14-34^{\circ} \mathrm{c}$

Mean annual rainfall:

$50-1200$

$\mathrm{mm}$.

\section{Seed ecology and seedling development}

Mesquite propagates only through seed. Mesquite seed occurs in long pods (legumes) around 6-10 inches long and comprise 8-24 seeds per pod. Most of the pods which falls to the ground are eaten by ruminants or destroyed by insects. Within Soil seed remain viable for many years i.e. why much suitable for dry areas of the province. Mesquite pods do not burst out at maturity. Foraging animals that eat pods distribute mesquite seed through fecal after eating. Seeds when taken out of pods 
germinated in Pishin within 24 hours after processed in Soda. Germination is boosted if seed are processed by passage through animal digestive system [2].The author passaged it through digestive tract of donkey and germination was marvellous.

\section{Growth of mesquite}

Mesquite can raise up to 25 feet in height with main support stems as much as 2 feet in diameter mesquite which depend on the site and climate. Sapling mature as single to few-stemmed plants. Flowering begins shortly after leaf development. Leaf development starts shortly after March. In flowering period, mesquite trees have thousands of flowers but only few of these produce pods. Mostly pods are matured at August-September period.

\section{Root characteristics and water use patterns}

Mesquite is deep-rooted, water-using "phreatophyte" plant that resist drought [24]. In drought affected areas of Balochistan mesquite depends on shallow lateral roots system which is extended as much as $30 \mathrm{ft}$ from the plant .The author calculated roots up to 10 feet at district Pishin. Mesquite plant is extremely hard, scare water using plant that avoid drought .It can get water from the water table through its long taproot system. Taproots of the mesquite tree may reach a depth of 200 feet down into the soil as recorded. Furthermore, mesquite can also use water from surface part of the ground, liable to availability of water. Mesquite plant can easily and quickly shift itself from using one water source to the other. For several people, particularly farmers, mesquite plant is a pest as the plant competes with rangeland grasses for moisture. As mesquite trees have a long taproot which are used to find sufficient moisture for growth purpose. This feature allows mesquite plant to survive through severe drought. There are recorded instances of taproots of the mesquite tree reaching a depth of almost 200 feet down into the soil. The roots of the mesquite can redevelop into a plant even if the tree is completely cut down above the ground that make mesquite plant one tough tree to get rid of completely .Farmers believe that the mesquite removes water from the land that could be used for livestock and farming, thus getting title of notorious plant.

\section{Deforestation in Pakistan}

Pakistan has an alarming rate of deforestation. The report on the State of the World Forests (2009) published by the Food and Agriculture Organization (FAO) [25] shows that Pakistan has only $2.5 \%$ of its area covered under forest. The annual rate of deforestation in Pakistan is - $2.1 \%$ which is much high, no Asian country has the forest degradation rate higher than this [25]. High value added trees such as juniper pistachios, olive and other reserve trees are cut down for fuel-wood purposes or timber usage causing deforestation and degradation of land .For rehabilitation of scrubland and other areas, mesquite is suitable plant to mitigate pressure on our already meagre state of forest resources. Furthermore, the arid nature of much of the province of Balochistan is unsuitable for forestry practices [26] except mesquite (Table 1). In 2001 miles per hectares (mha ) area covered with forest of Khyber Pakhtun Khwa (KPK) province is $1.49 \mathrm{~m}$ ha, Panjab 0.44 ,Sindh 0.28,Balochistan 0.45 Gilgit Baldistan (GB) 0.32 and Azad Jamu Kashmir (AJK) 0.34 mha respectively [26].

\section{Materials and methods}

\section{Determining the prevalence of mesquite} plants within the selected areas

Study comprises of field data Acquisition and data assessment. Both North and South part of Balochistan were selected. Samples of mesquite pods were also collected from the field area for determining out antibacterial activity.

\section{Evaluation of in vivo multiple uses of mesquite plant through field survey}

Survey is an important method regarding collection of information on a particular object. Vegetation Survey is the assessment of occurrence of a particular (under study) plant in an area. A survey was carried out to 
assess the multiple uses of mesquite plant in vivo.

Table 1. Province wise forests cover statistics

\begin{tabular}{|c|c|c|c|}
\hline \multirow{2}{*}{ Province } & Land Area & Forest Area (1997) & Forest Area (2001) \\
\cline { 2 - 4 } & Area (mha) & Area (mha) & Area (mha) \\
\hline KPK & 10.17 & 1.52 & 1.49 \\
\hline Punjab & 20.63 & 0.46 & 0.44 \\
\hline Sindh & 14.09 & 0.27 & 0.28 \\
\hline Balochistan & 34.72 & 0.71 & 0.45 \\
\hline GB & 7.04 & 0.31 & 0.32 \\
\hline AJK & 1.33 & 0.33 & 0.34 \\
\hline Total & 87.98 & 3.6 & 3.32 \\
\hline
\end{tabular}

mha: miles per hectares (mha) area covered with forest of KPK Khyber Pakhtun Khwa province is 1.49 mha, Panjab 0.44 ,Sindh 0.28,Balochistan 0.45GB: Gilgit Baldistan, AJK: Azad Jamu Kashmir

Objectives of the survey

Main objective of the survey was to ascertain the general public knowledge about mesquite, assess mesquite plant uses; the objectives of the survey were assessed through interviews. Collecting information through interview is called interviewing .The questions were clear-cut and clear answer have been recorded through questioner (Table 2) so as to mainly satisfy the objectives of the survey. The survey was carried out in the selected areas mostly which had mesquite plant distribution. The data was collected both from North and South parts of Balochistan. The main aim was to know the general community judgment about mesquite plant. Survey was done on the basis of interviews.

Table 2. Questioner

\begin{tabular}{|c|l|l|}
\hline S. No. & \multicolumn{1}{|c|}{ Question } & \multicolumn{1}{c|}{ Answer } \\
\hline 1. & What is your view mesquite plant, is it useful or not? & Yes or No \\
\hline 2. & Is Mesquite plant have agriculture damage? & Yes or No \\
\hline 3. & How you ever used pods of mesquite plant? & Yes or No \\
\hline 4. & Are these plants scattered or in cluster form? & Yes or No \\
\hline 5. & Is mesquite plant a useful plant & Yes or No \\
\hline 6. & $\begin{array}{l}\text { Does mesquite plant damaging your agricultural farm } \\
\text { lands? }\end{array}$ & Yes or No \\
\hline 7. & Do you use Mesquite plant in House Construction? & Yes or No \\
\hline 8. & Does mesquite plant is used in Furniture? & Yes or No \\
\hline 9. & Are you involved in Mesquite sale/Marketing Business? & Yes or No \\
\hline 10. & How much income you get from Mesquite? & PKR \\
\hline 11. & $\begin{array}{l}\text { Do you think mesquite tree plays a vital role in } \\
\text { sustaining the livelihood of the rural poor? }\end{array}$ & Yes or No \\
\hline 12. & What is you educational level? & $\begin{array}{l}\text { Nil/Primary/High } \\
\text { Sch. }\end{array}$ \\
\hline
\end{tabular}

\section{To Assess in vitro the Anti-bacterial activity of alkaloid-enriched extracts from mesquite pods}

Plant extraction has become one of the most popular methods for research work. A study was carried out in the physiology laboratory of CASVAB, University of Balochistan to determine antibacterial activity of the mesquite seed pods collected from roadside plantation of mesquite plants at district Pishin Balochistan, Pakistan. The antibacterial activity against Gram-positive stain by the chloroform extraction method of alkaloid-enriched extract gained from mesquite pods was carried out in following two different methods. 


\section{Preparation of Dragendorff's reagent}

The Dragendorff's reagent which usually comprises of an acidic solution of the iodide complex of bismuth (III), has been commonly used for identification of alkaloids since 1867[27]. The preparation of the Dragendorff's reagent procedure was obtained from literature [23].

While preparing it, first basic bismuth nitrate $(.50 \mathrm{~g})$ was liquefied in the already mixed solvents $(5 \mathrm{~mL}$ of concentrated hydrochloric acid $+20 \mathrm{~mL}$ distilled water). Then, $2.50 \mathrm{~g}$ of potassium iodide was completely dissolved in this solution, which was then finalized to $50 \mathrm{~mL}$ with distilled water addition.

\section{Plant material}

Pods of mesquite were collected manually in the month of September, 2016 from roadside plantation of mesquite plant at Pishin, Balochisatn, Pakistan. Pods of mesquite were dried at 20 to $35{ }^{\circ} \mathrm{C}$ in a ventilated place which were later put in a grinder to dry powder $(1.3 \mathrm{~kg})$.

\section{Obtaining extracts}

The powdered plant was first extracted by filtration with hexane $(5 \mathrm{~L})$. The hexanic extract (HE, $6.50 \mathrm{~g}$ ) was obtained after passing the concentration in a rotary evaporator $\left(40^{\circ} \mathrm{C}\right)$. Then, the plant material was extracted with ethanol $(5 \mathrm{~L})$ by filtration, and this solution was concentrated under reduced pressure to yield the crude ethanoic extract (EE, $435 \mathrm{~g}$ ). Ethanoic extract (EE, $285 \mathrm{~g}$ ) solvent was made in aqueous $1.6 \mathrm{M}$ acetic acid $(\mathrm{AcOH}$, $250 \mathrm{~mL}$ ), and the subsequent solution was filtered completely to obtain the acid aqueous solution (AAS). Then, neutralization of acid aqueous solution was done with $\mathrm{NaOH} 2.0 \mathrm{M}$ up to $\mathrm{pH} 9.0$, converting it into the basic aqueous solution (BAS), which was later on extracted with $\mathrm{CHCl}_{3}$, and the resultant organic layer was washed out with brine, desiccated with $\mathrm{Na}_{2} \mathrm{SO}_{4}$ and concentrated under low pressure to produce the basic chloroformic extract (BCE, $0.72 \mathrm{~g}$ ).

Antibacterial activity was carried out by two different methods
Bacteria Culture were carried out in nutrient broth (Oxoid) for 24 hours at temperature $37{ }^{\circ} \mathrm{C}$. The basic chloroformic extract (BCE) was assayed against the Grampositive bacteria in plates having 5 well. The primary microorganisms' inocula were adjusted to the turbidity of $0.5 \mathrm{McFarland}$, and the last concentration was $0.9 \times 10^{6}$ cells/well. Samples were assayed in triplicate. The extract being diluted in a normal solution prepared in water-dimethyl sulfoxide $(80: 20 \mathrm{v} / \mathrm{v})$ and examined at the final concentrations of , 50, 25, 6.3, 6.3, and $0.8 \mu \mathrm{g} / \mathrm{mL}$ respectively. Samples were assayed in triplicate.

\section{The Plate agar diffusion (Inhibition zone) method}

In this method Nutrient Agar (NA) was used. First of all 500 micro liter of a uniform bacterial cell suspension of $M$. luteus, S. aureus, $S$. mutans and other were spread over on sterile Petri-dishes which was solidified at room temperature for 24 hours. The wells made after drying the plates were filled with extract suspension. The plates were later on incubated at $37^{\circ} \mathrm{C}$ for 24 hours and the inhibition zones were measured [28]. Three replicates were made for the treatment.

\section{Results}

Mesquite prevalence

Mesquite prevails both in North and South of Balochistan

Among North parts of Balochistan mesquite plants are scattered all over Loralai district, good patches of mesquite plants are found inside Loralai and its adjacent areas. Mesquite is spreading with the passage of time. The core zone is District Duki. In district Musakhel mesquite plants are scattered all over the District. Mesquite plants are found on large scale in district Barkhan with water channels which flow from Musakhel, mesquite plants reach Naharkot. Disrict Harnai which is located at $30 * 6 \mathrm{~N}$ latitude and $67^{*} 56^{\prime}$ longitude and at elevation around 2952 above sea level also had good patches of Mesquite plants. In Pishin, Quetta, Killa Abdullah and Killa Safullah 
naturally grown mesquite plants are rarely found instead mesquite are planted on roadside through plantation.

Among Southern districts, mesquite plants are found in Bibi Nani, Badhar, Sigugar and Gokurt areas of Bolan around water channels and seasonal streams. In whole of Jaffer Abad district mesquite are found scattered.In Jhal Magsi Gajan, Gandava and Panjuk are main areas of mesquite distribution. Mesquite plants are distributed all over the district, mainly inside Sibi Thal, Quat, Terri and in Mall. Mesquite plants grow highly in Lasbella where it is considered as weed plant.
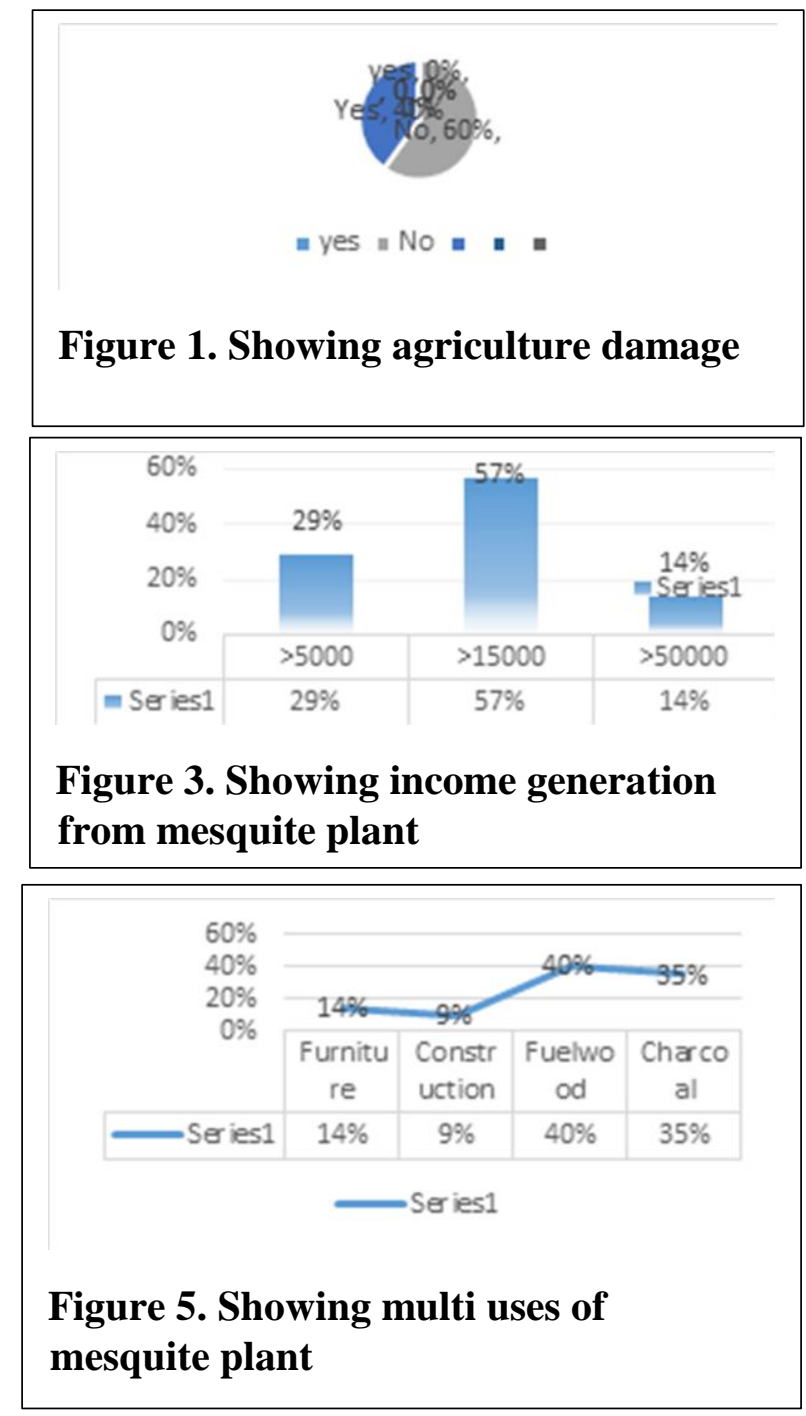

\section{Outcome of the survey}

The bean pods of the mesquite is edible. Mesquite pods provides good feed for cattle and is an excellent fuel wood. It should, therefore, be worthwhile to improve its
Mesquite plant is one of the most common tree of the legume family found both in North and South parts of Balochistan. This plant is ideally adaptable for arid zones of Balochistan as it requires less water and highly drought resistant. Mesquite grows in the Northern and Southern parts of Balochistan. Mesquite is found in areas having a low annual rainfall.

The advantages of the mesquite plant is more than the title of notorious weed plant given by ranchers. The public had pluralistic views about mesquite plant. Which is elaborated in figures $1,2,3,4,5$ and 6.

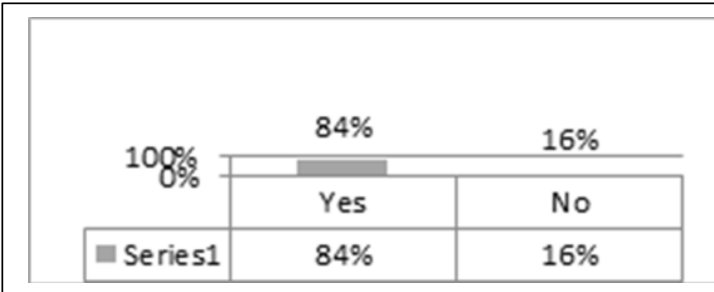

Figure 2. Showing respondent views about mesquite plant useful or weed

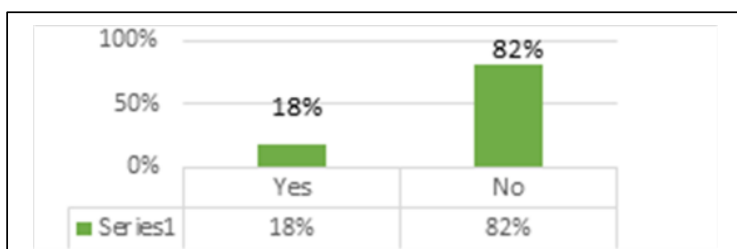

Figure 4. Showing marketing value of mesquite plant

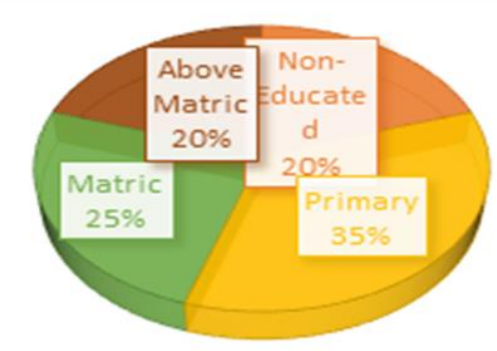

Figure 6. Showing educational level of respondent

stocking by artificial sowings and encouragement of natural regeneration through establishment of seed reserves at potential sites. 
The pods of mesquite palatable, and digestible for the animals' especially small ruminants. The pods of mesquite are rich in nutrient and fulfils the body requirement of animals. Since the availability of forage has become reduced pods of mesquite have become major source animal diet.

Mesquite is a good fuel wood and local population meets their energy requirement from the collection of mesquite branches etc. Mesquite burns very slowly .It is also used in brick and charcoal making industry. Mesquite is hard and it could be used in making furniture and tool handle. The wood is also used for decoration items.

Mesquite tree play important role in the environment, and provide habitat for many wildlife including animals and migratory birds. It is interesting to be noted that mesquite trees provide shade and wildlife habitat where other trees will not grow.

Mesquite is very good for sand dune stabilization in desert .In fact mesquite is tree of dry region. It could be used in desert areas for reclamation of sand dunes and generating a valuable source of income to the poor of the desert area. Exactly mesquite (Kabol) is a very resilient tree against drought thus is very suitable for dry areas.

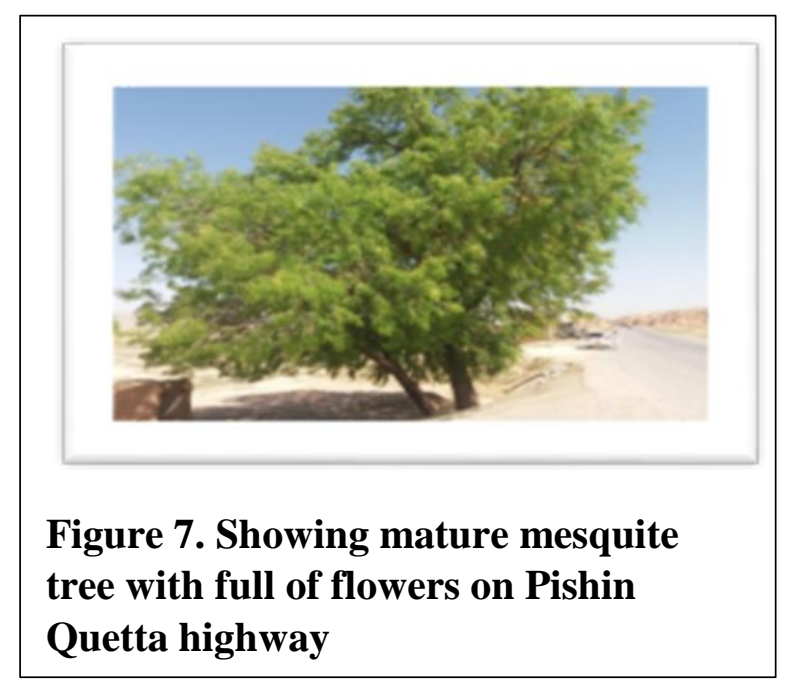

\section{Display of anti-bacterial activity}

The alkaloid-enriched extract BCE obtained from the pods of mesquite displayed Minimum Inhibitory
Mesquite's flowers offer a nectar source for honey bees to produce mesquite honey, which has a characteristic flavour. Figure 7 showing mature mesquite tree with full of flowers on Pishin Quetta highway.

Mesquite (Kabol) plays an important role in supporting the livelihood of the rural poor, tenants, farmers and artisans, due to all these it is called the tree of 'the poor'. In many rural areas, mesquite plant is usually the single major source of fuel, and fodder for dry season and generate income for many poor families. The large size branches and trunks of mesquite tree yield good quality timber.

Mesquite meal is obtained from the pods of the tree. Mesquite flour is sweet in taste, low in carbohydrate and fat concentration. It is rich in protein and have about 20 per cent protein as compared to the seeds which have up to 40 per cent protein). Mesquite has good concentration of calcium, manganese, potassium, iron, zinc and high in fiber and lysine.

Root of mesquite plant at Pishin, Balochistan was calculated roots up to 10 feet at District Pishin by the authors which shows its resilience against drought as showed in figure 8.

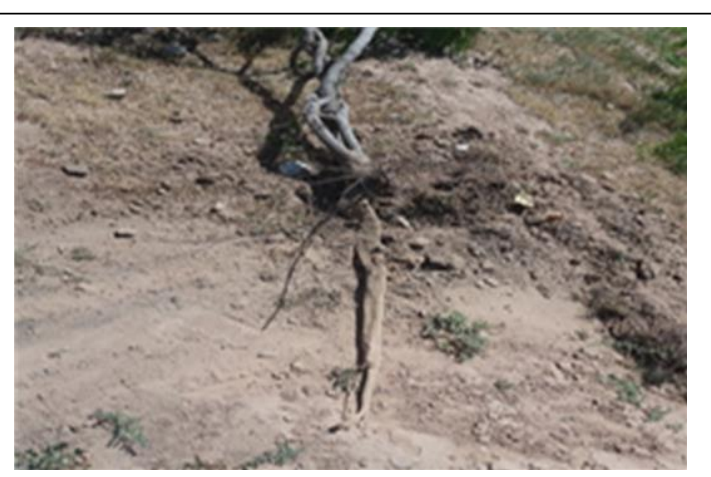

Figure 8. Showing roots of mesquite plant
Concentration (MIC, $\mu \mathrm{g} / \mathrm{mL}$ ) as showed in table 3 which represents overall MIC values and table 4 showing overall zones of inhibition. 
Table 3 and 4 revealed that the basic chloroformic extract (BCE) was active against $M$. luteus (MIC $=25 \mu \mathrm{g} / \mathrm{mL}$ ), $B$.

Table 3. Showing overall MIC values in table

\begin{tabular}{|c|c|c|c|c|}
\hline S. No. & Bacteria & Agent & $\begin{array}{c}\text { Antibacterial } \\
\text { activity }\end{array}$ & $\begin{array}{c}\text { MIC } \\
(\boldsymbol{\mu g} / \mathbf{m l})\end{array}$ \\
\hline 1. & M. luteus & $\begin{array}{c}\text { basic chloroformic } \\
\text { extract }\end{array}$ & + & 28.6 \\
\hline 2. & S. aureus & $\begin{array}{c}\text { basic chloroformic } \\
\text { extract }\end{array}$ & + & 26.5 \\
\hline 3. & S. mutans & $\begin{array}{c}\text { basic chloroformic } \\
\text { extract }\end{array}$ & + & 24.8 \\
\hline 4. & B. subtilis & $\begin{array}{c}\text { basic chloroformic } \\
\text { extract }\end{array}$ & + & 24.4 \\
\hline 5. & B.licheniformis & $\begin{array}{c}\text { basic chloroformic } \\
\text { extract }\end{array}$ & - & \\
\hline
\end{tabular}

Table 4. Showing overall zones of inhibition

\begin{tabular}{|c|c|l|l|}
\hline S. No. & Bacteria & Agent & $\begin{array}{l}\text { Zones of inhibition } \\
(\mathbf{m m})\end{array}$ \\
\hline 1. & M. luteus & basic chloroformic extract & 10.12 \\
\hline 2. & S. aureus & basic chloroformic extract & 10.4 \\
\hline 3. & S. mutans & basic chloroformic extract & 8.2 \\
\hline 4. & B. subtilis & basic chloroformic extract & 6.7 \\
\hline 5. & B. licheniformis & basic chloroformic extract & \\
\hline
\end{tabular}

Figures 9 and 10 showing plates displaying antibacterial activity again $B$. subtilis, B. lichniformis, S. mutan, and $S$. aureus while figure 11 showing measurement in millimeter $(\mathrm{mm})$ of zones of inhibition of B. lichniformis. It is checked optimal density (O.D) of positive control and basic chloroformic extract added to fermentation media .we kept $\chi 600 \mathrm{~nm}$. We obtained OD, 1.088 for positive control and 0.81 for extract added on UV-VIS spectrophotometer. Antibacterial activity of $\mathrm{BCE}$ against different bacteria showed via figures number 9 and 10

Table 3 and 4 showing Minimum Inhibitory Concentration (MIC, $\mu \mathrm{g} / \mathrm{mL}$ ) and zones of inhibition respectively for basic chloroformic (BCE) extracts which could licheniformis $(\mathrm{MIC}=25 \mu \mathrm{g} / \mathrm{mL}) S$. aureus $(\mathrm{MIC}=50 \mu \mathrm{g} / \mathrm{mL})$ and $S$. mutans $(\mathrm{MIC}=$ $50 \mu \mathrm{g} / \mathrm{mL}$. 


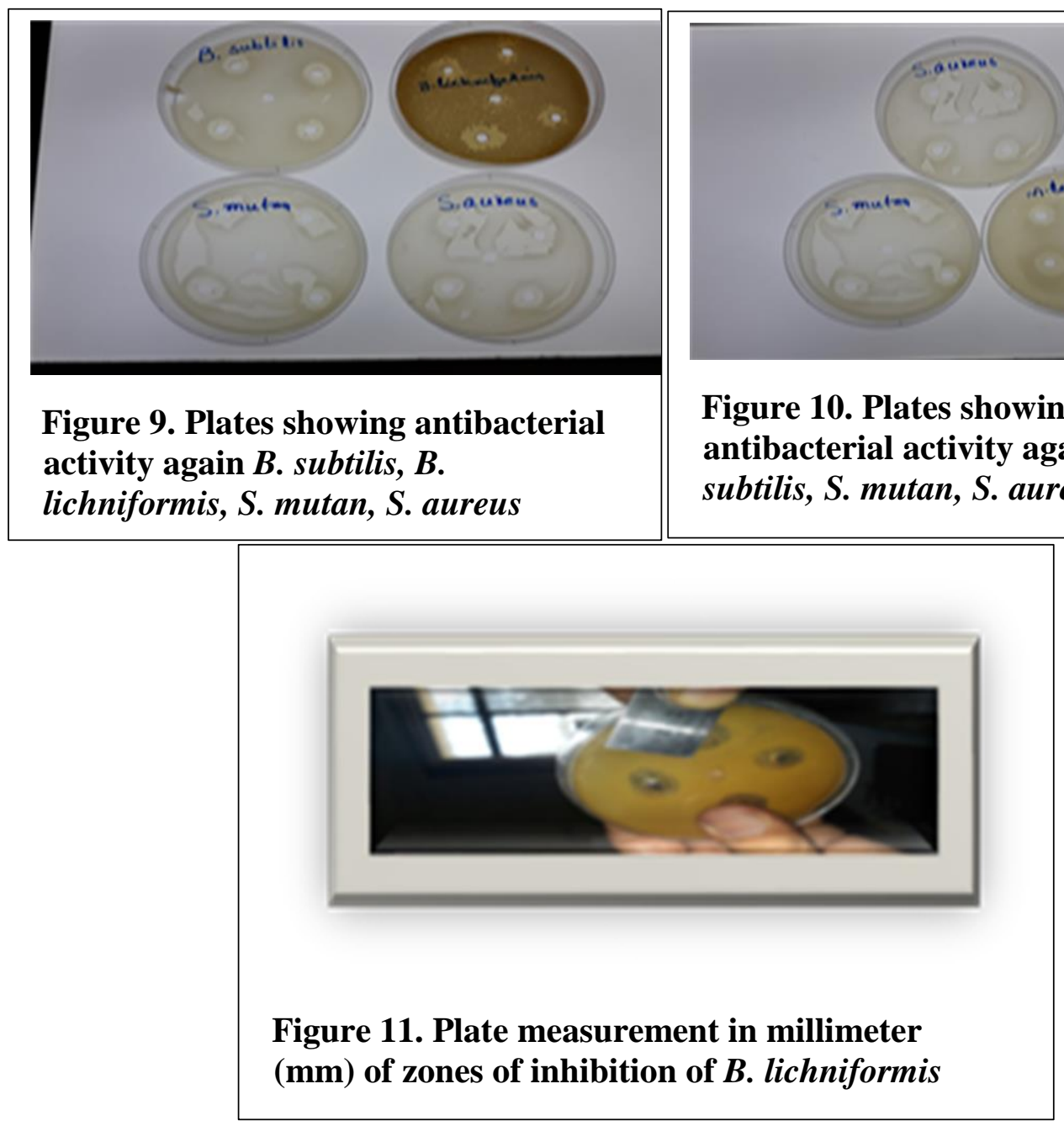

Results of the present study for screening antibacterial activity showed that the extract of mesquite (kabol) pods was effective against all tested bacteria. Which has also been reported in some previous works on the same [33-37]. The antibacterial substances not only protects mesquite against microorganisms but could also help pharmaceutical industries.

Survey indicated that mesquite was found in almost all selected districts of Balochistan either as wild or planted by Balochistan Forest and Wild Department for afforestation and sand dunes stabilization as was found in Gwadar district. Which has also been reported in previous studies [38]. The public had pluralistic views about mesquite plant which negates the previous title of being declared noxious weeds [39].

It was observed that 98 per cent land of Balochistan is barren land and dry as Balochistan is water scarce province. Balochistan has arid to hyper arid climate with very low precipitation levels. If an aerial campaign of mesquite sowing is started in these barren areas in collaboration with the Balochistan Forest and Wildlife Department, the meagre forest cover could be enhanced and pressure on reserve tree cutting would be reduced greatly. We can improve our range lands to a great extent in a short period of 5 to 10 years and improve the socioeconomic conditions of the local poor on one side and enhance the poor ratio of trees on the other by planting this multipurpose tree in drought affected 
districts as mesquite is deep rooted deeprooted water using "phreatophyte" which avoids drought [40].

\section{Conclusions}

The present study pointed out that mesquite prevails in Balochistan and its pods have antibacterial components. Besides this mesquite could be an alternative source of food for grazing animals if planted on large scale with proper management.

\section{Acknowledgement}

This research paper could not have been written without the wisdom, keen intellect, and unwavering commitment of the Prof Dr. Shakeel Babar, and Dr. Zia Uddin, members and colleagues from CASVAB. They have drawn upon their scholarship and extensive practical experience not only to produce this research paper but also to provide valuable advice and support to my efforts on my research work. Prof Dr. Muhammad Masod Tariq Kiyani in particular, has guided during whole research work, I am honored and grateful for his cooperation. I also owe a considerable debt of gratitude to my Forest and Wildlife Department, Balochistan officers for their extensive contributions and advice to the progress of this research work. This research work has benefited from these partnerships and input from dozens of farmers /interviewers from every walk of life.

\section{Authors' contributions}

Conceived and designed the experiments: M Essa, S Babar \& Z Uddin, Performed the Experiments: M Essa, Analyzed the Data: S Babar, Z Uddin \& M Essa, Contributed reagents/ materials/ analysis tools $\mathrm{S}$ Babar Z Uddin \& M Essa, Wrote the paper: M Essa.

\section{References}

1. Wyrwas B, Szymanski A, Lukaszewski Z, Tensammetric (1993) .Studies of the separation of surfactants. Part 1. Investigation of sources of error in precipitation of nonionic surfactants with modified Dragendorff reagent. Anal Chim Acta 278: 197-203.
2. Anslay RJ, Trevino BA \& Jacoby PW (1991). Honey mesquite root distribution in response to contrasting soil water regimes. Abstr. In: Proc. 42nd Annual Meeting, American Institute for Biological sciences (AIBS), San Antonio, TX.

3. Ansley RJ, Price DL, Dowhower SL \& Carlson DH (1992). Seasonal Trends in leaf area of honey mesquite trees.

4. Bicalho B, Gonçalves RAC, Zibordi APM, Manfiio GP, Marsaioli AJ (2003). Antimicrobial compounds of fungi vectored by Clusia ssp. (Clusiaceae) pollinating bees. $Z$ Naturforsch 58c: 746-751.

5. Archer S (1989). Have Southern Texas savannas been converted to woodlands in recent history. The American Naturalist 134: 545-561.

6. Archer S (1995). Tree-grass dynamics in a Prosopis - thornscrub savanna parkland: reconstructing the past and predicting the future. Ecoscience 2: 8399.

7. Barry AL, Garacia F \& Thrupp LD (1970). Interpretation of sensitivity test results. Am J Clin Path 53: 149

8. Bedunah DJ \& Sosebee RE (1984). Forage response of a mesquite-buffalo grass community following range rehabilitation. J Range Manage 37: $483-487$.

9. Burkhart A \& Simpson BB (1977). The genus prosopis and amotated key to the species of the world. Pp 201- 215 In: Mesquite - its Biology in two desert ecosystems (B.B simpson, Ed.)

10. Carlson DH, Thurow TL, Knight RW, \& Heitschmidt RK (1990). Effect of honey mesquite on water balance of Taxes Rolling plains rangeland. $J$ Range Manage 43: 491- 496.

11. CSDI (2008). Baseline survey on Prosopis in 3 Districts of Kenya. Report of Centre for sustainable Development Initiative (CSDI). Http://www.csdikenya.org/baselinepro sopissurvey.htm. 
12. Dahl BE, Sosebee RE, Goen JP \& Brumley CS, (1978). Will mesquite control with 2,4,5-T enhance grass production. J Range Manage 31: 129 131.

13. Davidow. Joic, infusions of Healing (1999) A treasury of MexicanAmerican Herbal Remedies. Simon and Schuster Inc., 149.

14. FAO (1987). Pakistan's experience in rangeland rehabilitation and improvement. Food and Agriculture Organization of United Nations. 70 pp.

15. Fisher CE, Meadors CH, Behrenns R, Robison ED, Marion PT \& Morton HL (1959). Control of Mesquite on grazing lands. Texas Agric-Exp Sta Bull Pp 935.24.

16. Gifford EW (1993). The cocopa. Uni of California Publications in American Archeology \& Ethnography 31:257334.

17. Government of Balochistan \& IUCN Pakistan (2000). Balochistan Conservation Strategy. IUCN Pakistan and GoB Karachi, Pakistan. 354 pp.

18. Hartwell JL (1971). Plants used against cancer. A survey. LIoydia; 30-34.

19. Heitschmidt RK, Ansley RJ, Dowhower SL, Jacaby PW \& Price DL (1988). Some observations from the excavation of honey mesquite root systems. J Range Manage 41: 227-231.

20. Hrdlicka, Ales (1908). Physiological and medical observations among the Indians of South Western United States $\&$ Northern Mexico. Bulletin of the Bureau of American Ethnology 34: 1460.

21. Khan AA (1961). Efficacy fo "Fernoxone" to prevent resprouting of cut-back Mesquite. Pakistan Journal of Forestry 11: 375 - 377.

22. Zhang Li S H, Qiu HJ, Niu SX, Santarsiero XM, Mesecar BD, Fong AD, Farnsworth HHS, Sun NR \& Vitexlactam HD (2002). A novel labdanediterpene lactam from the fruits of Vitexagnus-castus. Tetrahedron Lett 43:5131-5134.
23. Mendes BV (1988). Prosopis in Brazil. In: The current state of Knowledge on Prosopis juliflora Habit MA \& Saavedra, JC (Eds). FAO, Plant production and protection Division, Rome.

24. Mohammad N (1989). Rangelands of Pakistan: Their potential for development. In: shah BH \& Rafique SM, (eds.) proceedings of Regional seminar under RAS/79/121 FAO Regional project pp. $204-2014$.

25. NFRRAS (2004). National Forest \& Range Resources Assessment, Pakistan Forest Institute, Peshawar

26. Wyrwas B, Szymanski A \& Lukaszewski Z (1993). Tensammetric studies of the separation of surfactants. Part 1. Investigation of sources of error in precipitation of non-ionic surfactants with modified Dragendorff reagent. Anal Chim Acta 278: 197-203

27. Barry AL, Garacia F \& Thrupp LD (1970). Interpretation of sensitivity test results. Am J Clin Path 53: 149.

28. Marangoni A \& Alli I (1988). Composition and properties of seeds and pods of the tree legume Prosopis juliflora (DC). J Sci Food Agric 44: 99-110.

29. Singh S (2012). Phytochemical analysis of different parts of Prosopis juliflora. Int J Curr Pharm Res 4(3): 59-61.

30. Del Valle FR, Escobedo M, Munoz MJ, Ortega R \& Bourges H (1983) Chemical and nutritional studies on Mesquite Beans (Prosopis juliflora). $J$ Food Sci 48(3): 914-19.

31. Prabha DS, Dahms H-U \& Malliga $P$ (2014). Pharmacological potentials of phenolic compounds from Prosopis spp.-a review. $J$ coast life med 2(11): 918-24.

32. Tajbakhsh S, Pouyan M, Zandi K, Bahramian P, Sartavi K \& Fouladvand $\mathrm{M}$ et al. (2011). Invitro study of antibacterial activity of the alga Sargassum oligocystum from the 
Persian Gulf. Eur Rev Med Pharmacol Sci 15(3): 293-98.

33. Tajbakhsh S, Mohammadi K, Deilami I, Zandi K, Fouladvand M \& Ramedani E et al. (2008). Antibacterial activity of indium curcumin and indium diacetylcurcumin. Afr $J$ Biotechnol 7(21): 3832-35.

34. Talaro KP \& Talaro A (2002). In: Foundations in Microbiology. 4th ed. New York: Mc Grow Hill; 2002. Drugs, microbes, host-The elements of chemotherapy; pp. 348-79.

35. Forbes BA, Sahm DF \& Weissfeld AS (2007). In: Bailey \& Scott's Diagnostic Microbiology. 12th ed. St. Louis: Mosby Elsevier. Laboratory methods and strategies for antimicrobial susceptibility testing; pp. 187-214.

36. Tajbakhsh S, Ilkhani M, Rustaiyan A, Larijani K, Sartavi K \& Tahmasebi R et al. (2011). Antibacterial effect of the brown alga Cystoseira trinodis. J Med Plants Res 5(18): 4654-57.
37. Bokrezion H (2008). The ecological and socio-economic role of Prosopis juliflora in Eritrea. Academic Dissertation, Johannes GutenbergUniversitat Mainz, Germany. (Ph.D report).

38. Ahmad RS, Ismail \& Khan D (1986). Saline Agriculture at Coastal Sandy Belt. Final Research Report. Coordinated Res. Prog. On Saline Agriculture, Karachi University and PARC, Islamabad, 183 pp.

39. Essa S, Dohaib B \& Kriksia T (2006), Mapping dynamics of invasive Prosopis juliflora in the northern emirates of the Uae: An application of remote sensing and GIS, proceeding of ISPRS commission VII-Mid-term symposium "Remote sensing: from Pixel to processes. " Enschede, the Netherlands, 8-11 May 2006.

40. Mooney HA, Simpson BB \& Solbrig OT (1977). Phonology, Morphology, Physiology. Pp 26-41. 